\title{
Proceeding
}

Supplementary Issue: Spring Conferences of Sports Science. Costa Blanca Sports Science Events, 19-20 June 2020. Alicante, Spain.

\section{A systematic review about the characteristics and patterns of use of outdoor gyms}

\author{
EMILIO FRANCISCO FERNÁNDEZ-RODRÍGUEZ , RAFAEL MERINO-MARBAN, OSCAR ROMERO- \\ RAMOS, IVÁN LÓPEZ-FERNÁNDEZ \\ Department of Didactic of Physical Education, Faculty of Educational Sciences, University of Malaga, Spain
}

\begin{abstract}
The outdoor gyms have risen exponentially during the last years as a way of revitalizing public areas to enhance the practice of physical activity by insufficiently active older people. However, little is known about their use patterns that might help to maximize its benefits. To know the outdoor gyms profile, an exhaustive scientific literature review was made on research databases (WOS, Scopus, SportDiscus, CINAHL, Cochrane Library Plus, PubMed, Proquest Dissertations and Theses, and Google Scholar). Only 24 studies met the selection criteria of the 17,035 gathered. In general, outdoor gyms were used 3-5 days per week. They are 10-20 min away from users' home and distance was between 500 and $2007 \mathrm{~m}$. Most activities on outdoor gyms were a supplement of other main PA. More rigorous study designs (intervention programs) are needed. It is necessary to operate in a community setting with local government. Current studies have indicated the existence of potential safety risks due to inappropriate usage behaviours. The most demanded improvements were more instructors, benches, variety devices, small roofs over the equipment, toilets, maintenance, lighting the area, security city guards, better promotion and placing information signs. The average number of devices per outdoor gym was 4,6. The dimensions were between 100-200 m².

Keywords: Review; Physical activity; Fitness zones; Open gyms; Equipment; Outdoor gym profile.

\section{Cite this article as:}

Fernández-Rodríguez, E.F., Merino-Marban, R., Romero-Ramos, O., \& López-Fernández, I. (2020). A systematic review about the characteristics and patterns of use of outdoor gyms. Journal of Human Sport and Exercise, 15(3proc), S688-S707. doi:https://doi.org/10.14198/jhse.2020.15.Proc3.21
\end{abstract}

Corresponding author. Department of Didactic of Physical Education, Faculty of Educational Sciences, University of Malaga, Boulevard Louis Pasteur, 25, 29010, Málaga. Spain. https://orcid.org/0000-0002-5329-5813

E-mail: effernandez@uma.es

Supplementary Issue: Spring Conferences of Sports Science. Costa Blanca Sports Science Events, 19-20 June 2020. Alicante, Spain.

JOURNAL OF HUMAN SPORT \& EXERCISE ISSN 1988-5202

(c) Faculty of Education. University of Alicante

doi:10.14198/jhse.2020.15.Proc3.21 


\section{INTRODUCTION}

People are becoming less active as they grow old. WHO $(2013,2017)$ and the USA Department of Health and Human Services (2018) reports state that risk reductions routinely occur on levels of at least 150-300 minutes per week of moderate-intensity aerobic physical activity (PA) during the week or, at least 75-150 minutes of vigorous-intensity aerobic throughout the week; balance and prevent falls; muscle-strengthening activities. When seniors cannot achieve the recommended amounts of PA due to health conditions, they should perform as much PA as their abilities and conditions allow. To guide public health practice, ecological social models have been recommended. These describe the interactions between people and their social and physical environment (Golden \& Earp, 2012; Lee, Lo \& Ho, 2018). That's why the use of safe outdoor public spaces is one of the ways to improve practice of PA (McCormack, Rock, Toohey \& Hignell, 2010).

For public health institutions, strategies focused on changing environmental contexts to facilitate healthy behaviours are at lower unit cost that care in medical prescription or hospitals (Frieden, 2015). So, a popular strategy is the outdoor gym (OG) installation (Copeland et al., 2017; Del Campo, Bermúdez, Peluffo \& Del Campo, 2016). An OG is defined as fixed exercise equipment placed in an outdoor area that is freely accessible to the public, to promote structured PA through strength, aerobic and stretching devices (Cohen, Marsh, Williamson, Golinelli \& McKenzie,2012; Cranney, Shaw \& Phongsavan, 2018; Lee et al. 2018).

The terms used for the designation of these OGs are miscellaneous. Table 2 shows the most common names used by authors, countries and focus. In English language the most used are outdoor gyms, outdoor fitness equipment, fitness zone, open fitness zones, senior playground, family recreation zones or golden age gym. In the Spanish language there was a transition from "parques biosaludables" (Hernández, FernándezRodríguez, Merino-Marbán \& Chinchilla, 2010) to "gimnasios al aire libre denomination" (Del (Campo et al., 2016). Most studies have been conducted in Brazil. The term "academia ao ar livre (AAL) is the most common in the Portuguese language. In this paper we have preferred to use the term OG (GAL in Spanish and AAL in Portuguese language) because, unlike others, it makes it clear that it is done outdoors as well as being the most used.

Incorporation of people with poor or no exercise habits into the realm of regular exercisers is the main reason for building OGs parks. The finding that two out of five OG users did not do any type of PA immediately prior to the installation of $O G$ suggests that they are successful in overcoming people's sedentary behaviour (Mora, 2012; Mora, Weisstaub, Greene \& Herrmann, 2017). Others purpose of OGs are to enhance the practice of PA by insufficiently active people. Generally, for adults or older, this exercises equipment uses the practitioner's body mass (Silva et al., 2017). These sport facilities are contributing to the revitalization of the public spaces (parks, squares...) in which they are located (Chow, 2013; Chow, Mowen \& Wu, 2017; Furber, Pomroy, Grego \& Tavener-Smith, 2104; Lima, 2013; Mora, 2012). Increasing the accessibility of OGs through good design, location and promotion could be an important public health strategy to increase PA among at risk populations (Cranney, Shaw, Phongsavan, 2018). OGs can contribute users' PA and attract people with sedentary lifestyles to exercise (Mora et al., 2017). But OGs success depends on different elements; complement such as fountains, shadows, good maintenance, PA teachers and others. The targeted marketing is important in the success of the OGs and, is favouring that users commute to it walking or biking (Costa, De la Rocha Freitas \& Silva, 2016; Del Campo et al., 2016).

Some reviews have been made about OGs. The review by Lee et al. (2018) synthesizes the design, the main user group and the terminology used for the OG of nine studies. It gives an overview of how users and neighbourhood residents from different cultural backgrounds perceive this type of environmental 
infrastructure related to PA. Objectives of its study were to support knowledge of OGs and identify recurring themes related to experiences and perceptions of OGs through qualitative and quantitative data synthesis. Jansson, Lubans, Smith, Duncan, Haslam \& Plotnikoff (2019) review, examine the effects of OGs on community-based PA, on individuals and other health-related outcomes of 18 studies. Other objectives were to describe the features, user characteristics, and use of OGs. The review by Fernández-Rodríguez, MerinoMarban, Romero-Ramos \& López-Fernández (2020) have many coincidences with that carried out by Jansson et al. (2019); reference, citation number, country, sample, size, participants, outcome measure, terminology, number and types of equipment / exercises, supervision... It included 22 studies that met the selection criteria. Also, it included many countries (South and North America, Asia, Europa and Australia). The highest frequency of OGs older users were female; married; with medium income, high school, live close to OGs and physically active on leisure time. They used the OGs between three to five times per week. Curiously, their perceived health is good, but they are overweight or obese, normally they are medicated, and many users suffer from chronic diseases. Consequently, the aim of this current systematic review study was, to analyse what the published literature shows regarding the OGs profile in relation with the used patterns by users of OGs.

\section{METHODS}

The following eight electronic bibliographic databases were searched through until October 2019: Web of Science (all databases), Scopus, SportDiscus, CINAHL, Cochrane Library Plus, PubMed, Proquest Dissertations and Theses, and Google Scholar. The searches were carried out in the search field type "Title, abstract, and keywords" or equivalent (e.g. "Topic" for the Web of Science database). Any publication format including journal papers and grey literature (i.e. master/doctoral dissertations and conference proceedings) was examined. Additionally, no language or publication date restrictions were imposed.

The search terms used were based on one concept. This concept included terms related to outdoor gym (geriatric park, open gym, outdoor fitness equipment, fitness zone, senior exercise park, elderly fitness, fitness corner...). Additionally, the keywords that consisted of more than one word were enclosed in quotes. Finally, the terms were combined with the Boolean operator "OR" (Cooper, Hedges \& Valentine, 2009). Based on the results of the Boolean-based search (as well as all the related studies by Léger), other modes of searching were carried out. The reference lists of all studies were manually searched. Furthermore, the reference citations (in the Web of Science and Scopus databases) and the researcher publications of the first authors (in the Web of Science and Scopus databases) were also examined.

\section{Inclusion and exclusion criteria}

Studies were included if they (1) Investigated profile of OGs users as the main focus; (2) Explored the views and perceptions of OGs either quantitatively or qualitatively; (3) Were peer-reviewed journal articles. Studies were excluded if they (1) Mainly explored PA experiences in green spaces or parks; or (2) contained insufficient data for analysis/synthesis (Lee, Lo \& Ho, 2018). Risk of bias was assessed by three reviewers. Any discrepancies regarding quality ratings were resolved with a fourth.

\section{Results study description}

Of the 17,035 bibliographic databases search results, 95 potentially relevant publications were retrieved for a more detailed evaluation (Studies excluded based on selection criteria were 75). Afterward, based on the studies of the Boolean-based database search, 31 additional records were identified through other sources (24 excluded based on selection criteria) Finally 24 studies met the selection criteria (Figure 1). 

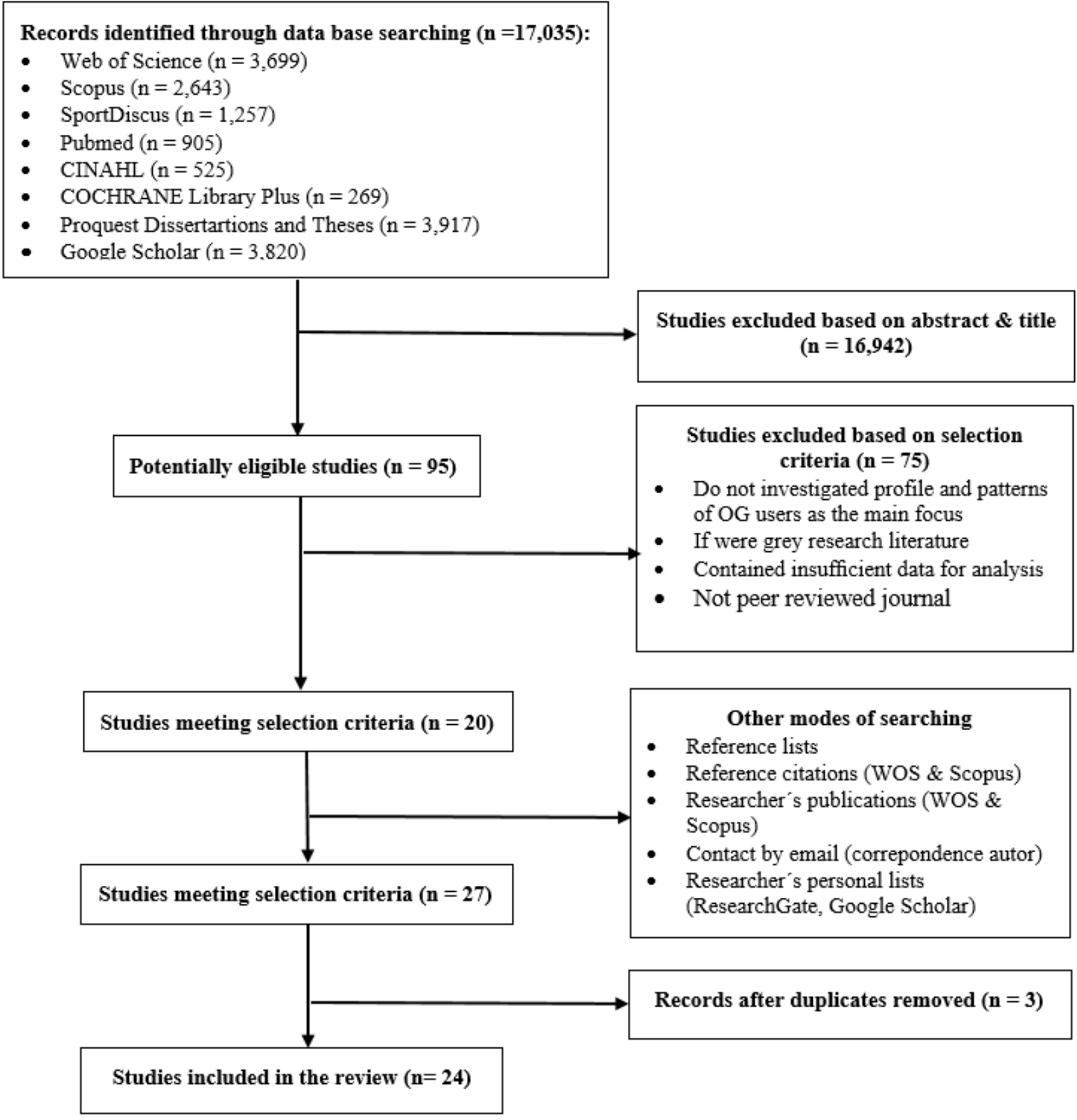

Figure 1. Flow chart of selection process.

\section{RESULTS}

We understand as an OGs' profile all those urban and environmental components that affect their use; the physical appearance (size, square meters, distance between pieces of equipment, number and quality of machines...); complements that improve it (drinking fountains, benches, shades, toilets...), maintenance (cleaning, lighting...) and, ultimately, all those things that show at the user as they are.

The machines usage profile (OG parks) refers to how they are used (how, when, which ...) if they are used well, badly or safely. The literature, generally, analyse the users' profile (table 2). For a better understanding, 
results of general elements of the OGs are, also, presented. The sections included in this review are presented in Table 1.

Table 1. Sections included in this review.

\begin{tabular}{|l|}
\hline General data \\
\hline Barriers / Disadvantages \\
\hline Closeness / Distance \\
\hline Comparison between OGs \\
\hline Data collector and methodology \\
\hline Facilitators \\
\hline Favourite equipment \\
\hline How many days are the OGs used? \\
\hline Instructional exercise \\
\hline Measurements \\
\hline Target \\
\hline Time-duration, long-term loyalty and seasonality \\
\hline Urban design \\
\hline When? morning or afternoon \& weekday or weekend \\
\hline OGs, who uses them? \\
\hline
\end{tabular}

\section{General data}

The table 2 shows authors (numbering codes), the publication year, OGs' names, origin and focus included in this systematic review. Onwards, in order to abbreviate the tables, each paper included in this systematic review, will be associated with a number (Table 2).

Table 2. Authors and code (numbering), year, terms and acronym, countries and focus.

\begin{tabular}{|c|c|c|c|c|}
\hline Authors & Paper-year & Name & Country & Focus \\
\hline $1=$ Bettencourt \& Neves & 2016 & $\begin{array}{l}\text { Senior playgrounds (SP) } \\
{ }^{*} \text { Parques geriatricos }\end{array}$ & Portugal & User' profile \\
\hline $2=$ Chow & 2013 & $\begin{array}{l}\text { Outdoor fitness equipment } \\
\text { (OFE) }\end{array}$ & Taiwan & User' profile \\
\hline $3=$ Chow, Mowen \&Wu & 2017 & $\begin{array}{l}\text { Outdoor fitness equipment } \\
\text { (OFE) }\end{array}$ & Taiwan & User' profile \\
\hline $4=$ Costa et al. & 2016 & $\begin{array}{l}\text { Academias ao ar livre (AAL) } \\
{ }^{*} \text { Open fitness zones (OFZ) }\end{array}$ & Brazil & Users' perception \\
\hline $5=$ Del Campo et al. & 2016 & $\begin{array}{l}\text { Gimnasios aire libre (GAL) } \\
\text { *Outdoor Gyms (OG) }\end{array}$ & Uruguay & $\begin{array}{l}\text { Pattern/user } \\
\text { profile }\end{array}$ \\
\hline $6=$ Ibiapina et al. & 2017 & $\begin{array}{l}\text { Outdoor fitness equipment } \\
\text { (OFE) } \\
{ }^{*} \text { Academias ao ar livre (AAL) }\end{array}$ & Brazil & User' profile \\
\hline 7 = lepsen \& Silva & 2015 & $\begin{array}{l}\text { Academias ao ar livre (AAL) } \\
{ }^{*} \text { Fitness Zones (FZ) }\end{array}$ & Brazil & User' profile \\
\hline $8=$ Mathias et al & 2018 & $\begin{array}{l}\text { Academias ao ar livre (AAL) } \\
{ }^{*} \text { Fitness zones (FZ) / GAL }\end{array}$ & Brazil & User' profile \\
\hline $9=$ Mora & 2012 & Open gyms (OG) & Chile & User' profile \\
\hline $10=$ Mora et al. & 2017 & Outdoor gyms (OG) & Chile & User' profile \\
\hline
\end{tabular}




\begin{tabular}{|c|c|c|c|c|}
\hline 11 = Nałęcz et al. & 2018 & Outdoor gyms (OG) & Poland & User' profile \\
\hline $12=$ Pinheiro \& Coelho & 2017 & Outdoor gyms (OG/AAL) & Brazil & User' profile \\
\hline $13=$ Ramirez et al. & 2017 & Outdoor gyms (OG) & Colombia & Users/OG profile \\
\hline $14=$ Salin et al. & 2014 & Golden age gym & Brazil & Users' perception \\
\hline 15 = Santos et al. & 2017 & $\begin{array}{l}\text { Academias ao ar livre (AAL) } \\
\text { * Outdoor gyms (OG) }\end{array}$ & Brazil & User' profile \\
\hline $16=$ Scott et al. & 2014 & Outdoor gyms (OG) & Australia & OGs' promotion \\
\hline $17=$ Silva et al. & 2016 & Academias ao ar livre/ *FZ & Brazil & OGs' injuries \\
\hline 18 = Silva et al. & 2018 & Fitness zones/ *AAL / *GAL & Brazil & Distance to OGs \\
\hline 19 = Silva et al. & 2017 & Fitness zones /*AAL & Brazil & User' profile \\
\hline $20=$ Souza et al. & 2014 & Academias ao ar livre/ ${ }^{*} \mathrm{FZ}$ & Brazil & $\begin{array}{l}\text { Pattern/user } \\
\text { profile }\end{array}$ \\
\hline 21 = Stride et al. & 2017 & Outdoor gyms (OG) & Australia & Enablers/barriers \\
\hline $\begin{array}{l}22 \text { = Szopa \& Sas- } \\
\text { Nowosielski }\end{array}$ & 2016 & Family recreation zones & Poland & Pattern' profile \\
\hline $23=$ Chow \& Wu & 2019 & $\begin{array}{l}\text { Outdoor Fitness Equipment } \\
\text { (OFE) }\end{array}$ & Taiwan & Use profile \\
\hline 24 = Levinge et al. & 2019 & Senior Exercise Park (SEP) & Australia & PA program \\
\hline
\end{tabular}

\section{Barriers and disadvantages for usage an OG}

The reasons that make an OG non attractive are indicated in Table 3. It shows the reasons indicated in the different articles of this review. There are more reasons associated with the OGs' profile than the users' profile. The most repeated reason was bad weather

Table 3. Main barriers to go to an OG.

\begin{tabular}{llll}
\hline Barriers & Papers & Barriers & Papers \\
\hline Cleaning & $12,13,22$ & Lack PA teacher & 22 \\
Children & 21,22 & Lack of a roof & 22 \\
Comfort & 1 & Maintenance & 13,22 \\
Crowding & 21,22 & Modest machines & 22 \\
Damage machines & 22 & Painting & 13,22 \\
Deck/pavement- quality & 2 & Safety & 20,22 \\
Bundles and seats comfort & 2 & Bad weather & $1,11,21,22$ \\
Too much distance & 19,21 & & \\
\hline
\end{tabular}

OGs, closeness or distance

Table 4. Main time or distance to go to an OG.

\begin{tabular}{ll}
\hline Papers & Time / metres \\
\hline 6 & $0-10$ minutes \\
7 & $11-20$ minutes \\
9,10 & $500 \mathrm{~m}$ \\
& $5-20$-minute walk, \\
11 & $5-10$ minutes bike/public transport \\
& $5-3$ minutes by car \\
18 & $2007 \mathrm{~m}$ \\
\hline
\end{tabular}


Table 4 shows the time or distance to go to an OG. Arrival time to an OG from home is variable. In Ibiapina et al. (2017) study, most users (63\%) take up to 10 minutes to reach the OG but, in lepsen \& Silva (2015) study most users take more than 30 minutes, although $71 \%$ of users find it easy to walk from home to the OG. Attending to Mora (2012) and Mora et al. (2017) study, in some cases, a $64 \%$ of the households found an OG within 500m. Silva, Fermino, Santos Lopes, Alberico \& Reis (2018) found that mean distance from home to fitness zone was 2,007 meters.

Comparison between parks; studies

Table 5. Comparison studies between OGs. Intervention program and senior/older words in title.

\begin{tabular}{|c|c|c|}
\hline Reason & $\mathrm{N}^{\circ} \mathrm{OGs}$ & Research \\
\hline To analyse geographic accessibility and proximity & 2 & $1^{*}$ \\
\hline \multirow[t]{2}{*}{$\begin{array}{l}\text { To assess sizes, locations, population, proportion of older adults, and } \\
\text { socioeconomic status }\end{array}$} & 2 & $2^{*}$ \\
\hline & & 3 \\
\hline $\begin{array}{l}\text { To compare sociodemographic characteristics, perceived use of equipment and } \\
\text { the practice of MVPA among attendees }\end{array}$ & & 4 \\
\hline To describe and analyse the characteristics of use and users & 3 & 5 \\
\hline To verify the characteristics of the users and the usage pattern of OGs & 22 & 6 \\
\hline To verify the profile of the users of OGs located in the urban perimeter & 3 & 7 \\
\hline To analyse the functioning of four recently installed OGs & 4 & 8 \\
\hline To record of all existing OGs in Santiago (Chile) and socioeconomic parameters & 4 & 9 \\
\hline To registry of the location of all existing (OGs) in Santiago, Chile & 1981 & 10 \\
\hline To analyse the use of OGs in Warsaw and selected surrounding settlements & 49 & 11 \\
\hline To compare two groups: average income of the neighbourhoods & 11 & $12^{*}$ \\
\hline To describe the characteristics of $O G$, their users and their level of PA & 10 & 13 \\
\hline To describe the perception of older adults (motivation for entry and permanence) & 15 & $14^{\wedge *}$ \\
\hline \multirow[t]{2}{*}{ To describe the $O G$ user profile, guided and not guided by professionals of PA } & 2 & $15^{\wedge}$ \\
\hline & & $16^{\wedge *}$ \\
\hline $\begin{array}{l}\text { To determine the association between injuries and PA among adults who use } \\
\text { FZ }\end{array}$ & 20 & 17 \\
\hline To analyse the association between distance from home to fitness zones & 20 & $18^{*}$ \\
\hline To verify the adequate practice of PA and associated factors among OGs users & 3 & 19 \\
\hline \multirow[t]{2}{*}{$\begin{array}{l}\text { To identify the profile of the users, pattern use \& and association between these } \\
\text { and neighbourhood income }\end{array}$} & 20 & 20 \\
\hline & & $21^{*}$ \\
\hline To examine how the relatively new initiative supporting active leisure of people & 5 & 22 \\
\hline \multirow[t]{2}{*}{ To analyse how outdoor gyms are used } & **49 & $\star * 11,23$ \\
\hline & & $24^{\wedge *}$ \\
\hline
\end{tabular}

Note: ${ }^{\wedge}=$ intervention studies; ${ }^{*}=$ words in title: senior, older.

Most researches compare more than two OG parks to better understand the element to study (Table 5). It is observed that the majority compare less than five OGs. It is followed by a group of articles that compares between five and 20 parks. The article by Nałęcz, Ostrowska-Tryzno \& Pawlikowska-Piechotka (2018) compare 49 OGs in different areas of Warsaw. Only the article by Mora et al. (2017) includes 1981 OGs since it is a descriptive study that registers the location of all existing OGs in Santiago (Chile). The authors' aims to make a comparison between OGs are shown in table 5. Also shows the intervention programs and 
those articles where the words "older / senior..." appears in the title. There are only four intervention articles and in eight, the words older / senior appears in the title.

\section{Data collection and methodology}

Table 6 shows data collection tools and methodology. Basically, they were interviews, questionnaires and various types of observations.

Table 6. Data collection and methodology used in the different researches.

\begin{tabular}{|c|c|}
\hline Methodology data collection & Researches \\
\hline \multicolumn{2}{|l|}{ Observation } \\
\hline Observation. SOPARC; ${ }^{*} 3=$ Case Study; ${ }^{*} 13=$ cross-sectional study & *3, *13 \\
\hline Observation. No participant systematic observation & 1 \\
\hline Observation (without specifying) and short survey; *twofold & *9 \\
\hline \multicolumn{2}{|l|}{ Interviews } \\
\hline Interviews. Structured Interview: Descriptive cross-sectional study & *4 \\
\hline $\begin{array}{l}\text { Interview \& others: Structured interview \& survey by standardized questionnaire } \\
\text { participant and non-participant undisguised observation }\end{array}$ & 11 \\
\hline Interview. Semi-structured guide \& peer debriefing; *qualitative fieldwork & *2 \\
\hline Interview. Semi-structured interview or survey; descriptive study & *14 \\
\hline Interview; Descriptive cross-sectional study & *8 \\
\hline Interview. Survey \& GPAQ questionnaire & 10 \\
\hline \multicolumn{2}{|l|}{ Questionnaire and / other } \\
\hline $\begin{array}{l}\text { Filling out a form \& observations; Descriptive, exploratory, cross-sectional \& a } \\
\text { quantitative research }\end{array}$ & *6 \\
\hline $\begin{array}{l}\text { Questionnaire. Structured and semi-structured; *Descriptive cross-sectional } \\
\text { study }\end{array}$ & *12, *15 \\
\hline $\begin{array}{l}\text { Interview, survey or questionnaire without specifying the type of interview *7= } \\
\text { descriptive; }{ }^{*} 18=\text { cross-sectional study; }{ }^{*} 19 \text { cross-sectional observational }\end{array}$ & $\begin{array}{l}1,5,{ }^{*} 7,16,17, * 18 \\
\quad * 19,20,21,22\end{array}$ \\
\hline International Physical Activity Questionnaire (IPAQ) & $7,17,18,19,20$ \\
\hline $3 Q-P A$ & 21 \\
\hline Video Content Analysis & 23 \\
\hline Multi-site prospective study & 24 \\
\hline
\end{tabular}

Facilitators. Recommendations of studies to improve use

Table 7. Main recommendations to improve the use of OGs.

\begin{tabular}{|c|c|c|c|c|c|c|c|c|}
\hline Facilitators & $\begin{array}{l}\text { More } \\
\text { instructor }\end{array}$ & Benches & Shades & $\begin{array}{l}\text { Variety } \\
\text { machines }\end{array}$ & Toilets & Fountains & Accessible & Aesthetic \\
\hline Papers & $\begin{array}{l}6,11,14 \\
16,18,21\end{array}$ & $\begin{array}{l}11,14 \\
16,21\end{array}$ & $\begin{array}{l}3,11,14 \\
16,21\end{array}$ & $\begin{array}{l}11,14 \\
16,21\end{array}$ & 12,14 & 14 & 16 & 16 \\
\hline Facilitators & $\begin{array}{l}\text { Guides/ } \\
\text { marketing }\end{array}$ & Safety & Light & $\begin{array}{l}\text { More } \\
\text { activities }\end{array}$ & Cleaning & Painting & $\begin{array}{l}\text { Bike } \\
\text { stands }\end{array}$ & $\begin{array}{l}\text { Pet } \\
\text { waste }\end{array}$ \\
\hline Papers & 3,16 & $6,16,21$ & 16 & 14 & 6,13 & 6,13 & 16 & 13 \\
\hline
\end{tabular}

The most typical recommendations to improve OG use are shown in Table 8. Few papers describe if the machines have visible information. Ramírez et al. (2017) show that $81.8 \%$ had visible information about PA guidance and $27.3 \%$ had rules of usage. The most typical recommendations to improve OG use are presented in Table 7. 


\section{Favourite equipment}

The machines have low complexity of execution of the movements and, normally, the load can vary according to the body mass. Most users reported being satisfied with the quantity and quality of the available machines (Pinheiro \& Coelho Filho, 2017). The average number of pieces of fitness equipment per OG was 4.6 (Mora et al.,2017; Del campo et al., 2016). Most OGs have between 4 and 6. It is not uncommon to find some OG with more than 10, usually 12 . The most commonly used machines are shown in Table 8.

Table 8. Most widely used pieces of equipment and average number of machines per OG.

\begin{tabular}{llll}
\hline Research & Most used machines & Less used machines & Machines / OG \\
\hline 1 & surf, ski, scale & parallel, push-up, balance bars & $6-13$ \\
2 & arm stretch & & \\
3 & arm stretch, walker, twister & shoulder-arm wheel, bonny rider & \\
5 males & biceps press & & \\
5 females & hip side & ski walker, walking, double ladder & \\
6 & stretcher, Seated Row & & 4.6 \\
9 & & climbing wall, trampoline & $8-10$ \\
11 & surf treadmill, orbitrek, twister & & 12 \\
21 & back pull down & & \\
22 & arm/chest press & & \\
23 & air walker, triple waist twister, ski & &
\end{tabular}

How many days per week were the parks used?

Table 9 shows the predominant number of days of OGs use in the different papers.

Table 9. Predominant number of days per week of assistance.

\begin{tabular}{ll}
\hline Days $/$ week & Papers \\
\hline 1 & 21 \\
$2-3$ & 11 \\
3 & $7,9,10,17,19$ \\
3 to 5 & $6,8,18,20,22$ \\
$\geq 5$ & $2,4,12,22$ \\
\hline
\end{tabular}

\section{Instructional exercise}

Table 10. Researches where PA teachers were used. Other sessions promoted.

\begin{tabular}{ll}
\hline Research with exercise instructors & $6,14,15$, \\
& $16,17,24$
\end{tabular}
\begin{tabular}{l}
$\begin{array}{l}\text { Sessions promoted in newspaper, websites, flyers, posters, libraries, } \\
\text { community centres }\end{array}$ \\
\hline
\end{tabular}

It is the highest of older users' demand (Table 6). Table 10 shows papers where PA teachers were used. In general, $1 / 3$ of users who go to OGs alone, do not reach the PA recommendation (Cozzensa da Silva et al., 2017). Olders, in general, do not use OGs' machines vigorously (Chow 2013). In the other hand, communitybased interventions (with instructors) have shown to be effective in increasing and promoting PA (Levinge et al., 2019; Santos et al.,2017). 


\section{Measurements}

Few papers have established the size of the OGs or, the percentage into de park area. Ramírez, Camargo \& Quiroga (2017) are the only ones that indicate the \% of the OG within a public park. The space size in the different studies carried out was in Table 11.

Table 11. Outdoor gyms, physical activity area, park size area.

\begin{tabular}{llll}
\hline Paper & $\mathrm{m}^{2}$ & \% of PA area & $\%$ of Total park area \\
\hline 1 & $800 \mathrm{~m}^{2}$ & & \\
11 & $100-200 \mathrm{~m}^{2}$ & & \\
13 & $169.7 \pm 42.9 \mathrm{~m}^{2}$ & $2.6-13.4$ & $0.6-4.3$ \\
\hline
\end{tabular}

\section{Target activity or complement}

Most users consider their PA level active or very active (Del Campo et al., 2016; Mathias, Filho, Szkudlarek, Gallo, Fermino \& Silveira Gomes, 2018; Mora,2012), regardless of the use of the OGs.

According to the different studies, using OGs represents only a supplementary activity and most people use OGs to supplement main activities and are active when they commute to the OGs (Chow, 2013, 2017; Ibiapina et al., 2017; lepsen \& Silva, 2015; Mathias et al., 2018; Mora, 2012; Mora et al.,2017;Nałęcz et al., 2018; Pinheiro \& Coelho Filho, 2017; Salin, Virtuoso, Noronha Nepomuceno, Weiers \& Mazo, 2014; Silva, Fermino, Alberico \& Reis, 2016, 2018, 2017; Souza, Fermino, Rodriguez-Añez. \& Reis, ,2014).

\section{Time-duration, long-term loyalty and seasonality}

There are some differences according to authors and countries. The percentage of time spent exercising was very low. In general, at most, users spend 15-20 minutes on 3-4 favourite machines (Bettencourt \&Neves, 2016; Nałęcz et al., 2018) and some studies have observed that approximately half of the users only use one device and then leave. In general, no difference was found for total time of use based on gender. In a single machine they stay less than five minutes (Chow et al. ,2017; Nałęcz et al., 2018). According to Table 12, it can be seen that daily exercise recommendations are not always achieved.

Table 12. Average time (minutes) spent using all equipment and percentage of weekly time recommendation met.

\begin{tabular}{|c|c|c|c|c|c|c|c|c|c|c|c|}
\hline Research & 1 & 2,3 & 4 & 6 & 7 & 9 & 11 & 17 & 18 & 19 & $8,10, * 12,20,22$ \\
\hline $\begin{array}{l}\text { Time spent } \\
\text { (minutes) }\end{array}$ & $\begin{array}{l}1-30 \\
(7.7)\end{array}$ & $<9$ & & $\begin{array}{c}20 \text { to } \\
40\end{array}$ & 33 & $\leq 15$ & $\begin{array}{l}15- \\
20\end{array}$ & $\leq 30$ & $\begin{array}{l}30 \\
\geq\end{array}$ & $\begin{array}{l}30 \\
\geq\end{array}$ & $30 \geq$ \\
\hline $\begin{array}{l}\text { Number of } \\
\text { machines used }\end{array}$ & & & & & & & & $3-4$ & & & \\
\hline $\begin{array}{l}\% \text { Weekly PA time } \\
\text { recommendation } \\
\text { met }(\%)\end{array}$ & & & 72 & & & & & 73 & 72 & 75 & \\
\hline
\end{tabular}

Note: *Up to 30 minutes.

Regarding customer' long-term loyalty, some studies show a long period of OGs use over one year in lepsen \& Silva (2015) until 42,4\% of users (Chow, 2013; Ibiapina et al.,2017; lepsen \& Silva, 2015; Pinheiro \& Coelho Filho, 2017; Silva, et al. $(2016,2018,2017$; Souza et al., 2014). Family income and time spent in the places (months) were positively associated with neighbourhood income (Souza et al., 2014). Regarding the time of use the OGs, the data of lepsen \& Silva (2015) are representative of most of the authors. First time they attend, $14 \%$; few weeks, $10.9 \%$; one month, $4.6 \%$; $1-3$ months, $9.6 \%$; 3-6 months, $7.4 \%$; $6-12$ months, $11.1 \%$ 
and more than 1 year 42.4\%. Seasonality is another important issue in park use and design. The seasons when the users visit the OGs most frequently are Spring, Summer and Autumn (sunny and rainless days) and OGs are not visited at extreme temperatures: on very cold days in winter or scorching days in summer (Nalecz et al., 2018). Just some few studies mention the climatic conditions in which the studies were carried out. Since weather greatly influences outdoor behaviour, table 13 shows the data in the studies that report it.

Table 13. Weather.

\begin{tabular}{lllll}
\hline Paper & Country & Season & Temperature & Humidity \\
\hline 2 & Taiwan & & $24.3^{\circ} \mathrm{C}$ & $77.2 \%$ \\
3 & Taiwan & September & $28.5^{\circ} \mathrm{C}$ & $68 \%$ \\
12 & Chile & December & $8.5^{\circ} \mathrm{C}$ to $22^{\circ} \mathrm{C}$ & \\
22 & Poland & August-April & $14^{\circ} \mathrm{C}$ to $22^{\circ} \mathrm{C}$ & \\
\hline
\end{tabular}

\section{Urban design}

Several characteristics of the built environment in urban cities are important predictors of PA, especially in commuting and leisure and presence, availability, access and quality of public open spaces for PA near home are positively associated to the use of those spaces for leisure and PA (Silva et al., 2018). It is customary to install them in a particular place. The most frequent location is inside a public park, in small squares or close to the beach. The presence, proximity and use of public spaces is associated with better physical, psychological and social well-being in the community (Mora, 2012; Souza et al.,2014) and the introduction of OGs in parks increases the assistance and PA level to them (Mora, 2012; Szopa \& Sas-Nowosielski, 2016). Co-locating OGs with walkways or cycleways is important to increase access for those living further away and facilitate combined OG use with walking and cycling (Stride et al., 2017). The fact that more vigorous activity was seen in the areas were the OGs were installed highlights the importance of such infrastructure in supplying the need to increase levels of PA in the population (Del Campo et al., 2016). The number of OG users increases in the period of time after installation (Cranney et al., 2016) and two out of five users of OGs did not carry out any PA prior to their construction. In its urban implementation, OGs are more prevalent in the poorer and more densely populated areas (Mora, 2012).

\section{When? morning or afternoon and weekday or weekend?}

Table 14. Users' preference between morning/afternoon and weekends/weekdays.

\begin{tabular}{lllll}
\hline Research & \% Morning & \% Evening & \% Weekend & \% Weekdays \\
\hline 1 & 17.8 & 20.9 & 61,2 & 38.8 \\
6 & & $*$ & 3,1 & 70 to 80 \\
9 & & 3 & 14 \\
12 & $*$ & $45-55$ & $47-53$ \\
13 & & & \\
20 & & 12.2 & 43.5 \\
22 & & & & \\
\hline
\end{tabular}
Note: * Preference but unspecified percent.

In both cases the use is similar. Table 14 and 15 show the preference for use in the morning / afternoon, on the weekend / weekdays or both. Studies cannot specify the predominance. Normally at weekends and during holidays, the use grows rapidly. On weekdays, OGs are particularly popular all day in late spring and in summer, (Chow et al. 2017; Nałęcz et al., 2018). As for the time of day, it may vary; the use is in the morning (Ramírez et al. 2017), in the morning or afternoon (Chow et al.2017) or at nightfall (Nałęcz et al.,2018). Habitually in summer, activity start at $8 \mathrm{~h}$ and reached the maximum at about $11 \mathrm{~h}$, descending around 
lunchtime and moving upwards after $18 \mathrm{~h}$. Few people use the gyms after $21 \mathrm{~h}$. In wintertime, activity start later, at $10 \mathrm{~h}$, and reached its peak at noon, but went down substantially as lunchtime approached. The use of gyms resumes right after lunch, and reached its maximum about $17 \mathrm{~h}$, again decreasing rapidly once the sun had set; $17 \mathrm{~h}$ in winter (Mora, 2012).

Table 15. Blend of weekday or weekend with morning or afternoon. Preference of use.

\begin{tabular}{ccccccc}
\hline Days & Weekdays & $\begin{array}{c}\text { Weekdays- } \\
\text { morning }\end{array}$ & $\begin{array}{c}\text { Weekdays- } \\
\text { afternoon }\end{array}$ & Weekend & $\begin{array}{c}\text { Weekend- } \\
\text { morning }\end{array}$ & $\begin{array}{c}\text { Weekend- } \\
\text { afternoon }\end{array}$ \\
\hline Paper & $6,{ }^{*} 9^{\mathrm{a}}, 12,20$ & $3,12^{\mathrm{b}}, 13$ & $12^{\mathrm{b}}$ & $3,4,{ }^{*} 9 \mathrm{~b}, 11$ & $12^{\mathrm{a}}, 13$ & $1,12^{\mathrm{a}}$ \\
\hline
\end{tabular}

Note: * 9a weekdays preference during the week in Summer. ${ }^{*} 9 b$ preference during the weekend in winter the week in Summer and ${ }^{*} 9 \mathrm{~b}$ preference during the weekend in winter. $12^{\mathrm{a}}$; on weekends the use is similar in the morning and afternoon (wintertime and summertime). $12 \mathrm{~b}$ During the week, OGs are used more in the evening than in the morning (wintertime and summertime).

OGs, who uses them?

Table 16. Research and age groups with their \% use of OGs.

\begin{tabular}{|c|c|c|c|c|c|}
\hline Paper & Child & Youth & $\begin{array}{l}\text { Young- } \\
\text { adult }\end{array}$ & Older-adults & Elderly \\
\hline 1 & $\begin{array}{l}\text { Child } \\
(0-14) 44.2\end{array}$ & $\begin{array}{l}\text { Youngster } \\
(15-24) 10.1\end{array}$ & $\begin{array}{l}\text { Adult (25-64); } \\
39.5\end{array}$ & & $\begin{array}{l}\text { Elderly }(+64) \\
6.2\end{array}$ \\
\hline${ }^{*} 2$ & & & & 50 and older & \\
\hline 3 & Children 11 & Youths 8.7 & Adults 36.7 & Seniors: 43.3 & \\
\hline 4 & $19-29 ; 8.8$ & $30-39 ; 12.6$ & $40-49 ; 23.3$ & $50-59 ; 31$ & $\geq 60 ; 24.2$ \\
\hline 7 & & $20-29 ; 7.7$ & $\begin{array}{l}30-39 ; 12.4 \\
40-49 ; 18\end{array}$ & $50-59 ; 26.9$ & $\begin{array}{l}60-69 ; 24.2 \\
\geq 70 ; 10.2\end{array}$ \\
\hline 8 & & & $18-39 ; 85.9$ & $40-60 ; 14,1$ & \\
\hline${ }^{*} 12$ & & & & & $\geq 60$ \\
\hline $13^{\wedge}$ & Children; $19.8 \%$ & & Adults; 61.5 & Adults; 61.5 & $\geq 60$ \\
\hline *14 & & & & & $\geq 60$ \\
\hline $15^{\wedge}$ & & & & $\star \geq 50$ & \\
\hline $16^{\wedge}$ & & & & $\geq 50 ; 85$ & \\
\hline 19 & $20-29 ; 7.7$ & $30-39 ; 12.4$ & $40-49 ; 18,6$ & $50-59 ; 26.9$ & $\geq 60 ; 34.4$ \\
\hline *21 & & & & $50-60 ; 66.4$ & $\geq 65 ; 33.6$ \\
\hline 22 & & Youths; 5 & Adults; 75 & & $\geq 60 ; 20$ \\
\hline 23 & Children & Teenager & & Adult & ${ }^{*}$ Senior; $47 \%$ \\
\hline
\end{tabular}

Only in the paper by Bettencourt \& Neves (2016), carried out in Portugal, children (0-14 years old) and young people (15-24) were the main users (42.2\% and $10.1 \%$.). Children normally were more likely to be attracted to play equipment and tend to be more physically active but this equipment is usually not suitable for children and may jeopardize their safety (Chow \& Wu, 2019). Table 16 shows the use of the different age groups. The people who went and practiced the most were adults (18-60 years old). Elderly people were only the main group when the study was recruiting an older people sample. In the observations carried out throughout the days and at different times, the seniors were a minority. Chow et al. (2017) monitor only 12 users/hour. According to Pinheiro \& Coelho Filho $(2017)$, Silva, et al $(2016,2018)$ only a little more than a third of the older people who participated exercised in the company of someone else. Usually, older users come to the gym alone while young people come in pairs or even in groups (Mora, 2012, Nałęcz et al.,2018; Pinheiro \& Coelho Filho, 2017; Silva et al., 2018,2017; Souza et al.,2014). 


\section{DISCUSSION}

Most original papers come from South America (especially Brazil). It seems that the name used to describe OGs has evolved from names that referred to the elderly to broader and more common names (Senior playgrounds to Outdoor fitness equipment, Open fitness zones, Open gyms or Outdoor Gyms). Outdoor Gyms $(O G)$ is the most used name. Researchers who initially used another name, in later articles change to OG. Regarding barriers and disadvantages for usage an OG, there are more causes associated with the OGs profile than the users' profile. In general, the most referred cause was bad weather. Among the causes of the OGs own profile, the most frequently referred to the lack of cleaning, maintenance, painting and the remoteness from the house. It seems that a careful environment is very important to want to use an OG.

Are the OGs far or close to the people? People will more likely use OGs close to their homes. The greater or lesser distance to the OGs influences a greater or lesser use of OGs. People who live near parks or squares, walking or running circuits and physical-recreational facilities, are associated with greater use of the facilities and higher levels of PA. Normally, OGs are used in higher proportion by local residents and were more frequent park users compared with general park users (Del Campo et al., 2016; Stride et al, Cranney et al., 2016). According to Silva et al. (2018), OGs with fewer machines (four) are closer to neighbours than those with more machines (six or more). The proximity from OGs to homes increases in $126 \%$ the probability of walking, while a greater number of fitness centres improves in $52 \%$ the probability of moderate to vigorous PA in leisure time. So, shortening distances and increasing the number of units could facilitate active commute and length of stay. But Mora et al. (2017) also indicated that OGs users do not necessarily go to the closest facility to their residence, but rather to the one that provides them with a more complete exercise routine, or that have a more convenient location in the city, either for esthetical or for security reasons. It seems that OGs near to neighbours are associated with greater use of the facilities and higher levels of PA. Local topography and sidewalk availability are associated with non-motorized modes of transport, whereas studies have demonstrated that urban density is a crucial factor in determining people's willingness to choose active modes of transportation and walking behaviour in older people depends, to a large extent, on street connectivity.

In some studies, distances and times were calculated with the Geographic Information System (GIS) using the street network in ArcGIS. In Mora et al. (2017) all OGs were mapped, an accessibility analysis was carried out. They employed the Network Analyst tool of Arc Gis, which allowed determination of an OG, within the city's urban grid, considering a specific radius. In this case, a radius of 500 meters was set, equal to a tenminute walk, a typical threshold used in urban studies. So, these studies can be a good reference.

Most papers have preferred to study users' profile or OG use patterns that OGs profile. It seems logical since the analysis of the former can improve the profile of the latter. In the methodology, the data collection tools are similar in most of the investigations in this review (table 6). In the observation highlights the use of System for Observing Play and Recreation in Communities (SOPARC), a digitized tool that allows thousands of observations to be collected comfortably since it is based on camera system. This allows to classify the PA level of the people observed as sedentary, moderate or vigorous. Also, the International Physical Activity Questionnaire (IPAQ) is used how complement to measure physical activity levels. Many authors do not specify adequately the type of methodology. Issue; sometimes the same tool is used with a different name. For this reason, that apparent methodological dispersion.

The effort perception on OG equipment is medium/strong (Chow, 2013; Silva et al., 2016). The equipment appears to be safe for users (Chow, 2013; Pinheiro \& Coelho Filho, 2017; Silva et al. 2016). In OGs, the 
$49.4 \%$ of users do not use any piece and the main reasons for not using some piece of equipment in the OGs was pain, they do not like it and non-anatomical machines (Ibiapina et al., 2017). About $31 \%$ of participants reported not knowing how to use OGs devices and $47.9 \%$ reported not controlling the use of equipment, and always using the same devices; $16 \%$ reported feeling discomfort during use. The $69 \%$ needed instruction to exercise; $23 \%$ reported having received instruction during the practical intervention (Costa et al., 2016).

In accordance with them, the occurrence of injuries is considerably lower $(3,4 \%)$ than reported due to the practice of physical leisure activities so, it seems to be safe for the physical integrity. Among the studies, in this review does not appear studies that have identified the factors associated with injuries during the practice of PA in OGs. But for lbiapina et al. (2017) $49.4 \%$ of the subjects do not use at least one piece of equipment because of some pain, do not like it or non-anatomical and for Chow and Wu (2019) a significant portion of user behaviours did not follow manufacturers' instructions, which might pose potential risks or actually cause injuries. Children were especially prone to act improperly. Their study provides empirical evidence indicating the existence of potential safety risks due to inappropriate usage behaviours that might lead to accidents and injuries while using OGs. This study is the only one that has categorized different patterns or types of user behaviours for the same devices, noting many runtime errors. A higher percentage of inappropriate behaviours was observed in children and seniors than in those in other age groups and this equipment is usually not suitable for children and may jeopardize their safety.

Attending to equipment or preferred devices. It is difficult to carry out, to compare, a global analysis because the OGs pieces of equipment are not the same between OGs. For gender, men preferred OGs devices for the development of muscle strength (parallel bars, bicep press, leg press and abdominal stretcher), women prefer devices that enhance aerobic capacity (walking, elliptical) and joint mobility (lateral hip) and for women, aerobics (Del campo et al., 2016; Nałęcz et al., 2018; Szopa \& Sas-Nowosielski, 2016). Those OGs that are used by more women, could have more aerobic machines? In other words, could we generate exclusive parks for men and others for women? On the other hand, the ratio of numbers of devices, usually, were similar (strength, aerobics, stretching). In general, few machines are used. In Chow et al. (2017) only 3.6\% used all stations of equipment and most users interacted with less than three of the available devices. Costa et al. (2016) indicated that $68.7 \%$ know how to use the machines and $31 . \%$ do not know, $70,8 \%$ always use the same device and $52.1 \%$ control the time they are on the device. Bettencourt \& Neves (2016) show that $44 \%$ of users do not get to exercise in a second machine. OGs users interacted with less than three or four of the available six OG stations in Chow et al. (2017) and Nałęcz et al. (2018). In OGs, the 49.4\% of users do not use any piece of equipment and the main reason for not using some piece of equipment in the OGs was pain, do not like it and non-anatomical devices (Ibiapina et al., 2017). It is uncertain if equipment needs to be tailored to gender or different age groups.

Lee et al. (2018) state that the number of equipment and the inclusion of functional types of equipment did not have a unified standard; whether or not there were the guiding principle behind the selection of the functional type of equipment is unclear. Generally, it is not known who or how the machines are decided and why. Further research is needed for exploring the design parameter". These authors indicated that:

Regarding recommendations, only in the study of Nałęcz et al. (2018) $60 \%$ of users believe that there is no need to introduce any changes to the OGs. The most frequent demands in papers (from highest to lowest) to improve OGs' use are more instructors, benches, shades and more variety of pieces of equipment. It is clear that the presence of teachers is necessary. How many days per week are the parks used? Most OGs are used between 3 and 5 days a week (per user). Few papers included a use of more than 5 days a week. 
Also, very few people use the OG only one day a week. The number of days users go to an OG could be used as an index to establish the monthly / annual maintenance plan (Bettencourt \& Neves, 2016).

In general, programming exercise sessions is important to increasing older adults' PA (Bettencourt \& Neves, 2016). Some authors point out that the lack of a PE professional, some fitness devices are underused (Ibiapina et al., 2017). These classes are important to prevent injury and improve strength, balance and flexibility. Santos Moreno, Oliveira Ferreira \& Cruz Siqueira (2017) concluded that most OGs users who are not guided by a PE professional report higher pain or limitations at the time of PA when compared to those oriented. About $77 \%$ never received instruction, $69.2 \%$ reported feeling need for instruction to better use the equipment and 23\% reported having received instruction (Costa et al., 2016). Thus, the lack of direct supervision could, to some extent, increase exposure to injury risk (Silva et al., 2016). When there are PA teachers, users request a longer follow-up by these professionals (Ibiapina et al., 2017). This research (Brazil), was the only one where $70 \%$ of the OGs have a teacher. In general, these are hired for a short time. In several studies women claim, more than men, the presence of PA teachers.

Regarding de size. It seems that the size of the OG is not as important as other aspects of it. However, it is true that, generally, the user wants a greater variety of machines and this could mean more space for them. Target" activity or complement? During the observation process it was seen that most users went to the OG because they were encouraged by other family members or friends, including their children or grandchildren. Attending to lepsen \& Silva (2015), around $33.7 \%$ reported that they moved there specifically to use OGs, and the other $66.3 \%$ used it as a complement to the main activity they performed, as walking. For $87 \%$ of the users, OGs are the only places where they do exercise. The percentage of individuals who reported walking in leisure time was $74.0 \%$, and of these, most walked at least three days a week. The individuals' average walking time was $58.1 \pm 25.2$ minutes per week and $66,3 \%$ used it because it is walking. Attending Stride et al. (2017), between 40 and $90 \%$ usually combined a visit at the OGs with other ways of sport and recreation: walk or run $(74 \%)$, bike ride $(15 \%)$, walking the dog, fitness classes, roller skating, swimming pool; even in Brazilian users, soccer (17.1\%). Definitely, it is common to see people going to the park for a walk, a jog or to perform other activities and end up using OG. They are not target. They are supplements but combining time in OG with other time of physical activity, $73.2 \%$ exceed $150 \mathrm{mi} /$ week (Costa et al.,2016), although in relation to the MVPA, only $19.8 \%$ met the 150 min per week recommendation.

What about urban design, the importance of the environment for permanence of older adults in PA programs, identified the feeling of well-being (60\%) and easy access to the place of PA (50\%) as very important factors (Salin et al. 2014). Urban design is a key factor. Mora (2012) indicates that "environments restrict the range of behaviour by promoting, and sometimes demanding, certain actions and by discouraging or prohibiting other behaviours. Urban planning, therefore, becomes a relevant variable in the fight against obesity" (p.496). It can be said that they are an important environmental variable contributing to the PA level of adults and older adults (Szopa \& Sas-Nowosielski, 2016). The practice of PA in OGs is associated with higher energy expenditure and users of these equipment perform more vigorous walking and PA more frequently than those who do not use them (Souza et al., 2014). Also, the finding that two out of five subjects or $25.9 \%$ (men) and $38.7 \%$ (women) in Mora $(2012,2017)$ did not do any type of PA immediately prior to the installation of OGs, suggests that they are successful in overcoming people's sedentary behaviour.

When? morning or afternoon and weekday or weekend? We can say that people go less or not much in winter, during the hottest hours in summer and at night, after $21 \mathrm{~h}$. There is little difference in the use of OGs between the morning and the afternoon or between the week and the weekend. More studies are needed in winters and to analyse what could improve its use during this season. Time-duration, long-term loyalty and 
seasonality. Although there is a percentage of users who abandon the OG, surprisingly there are a high percentage of loyal users. All the necessary resources must be applied to maintain and increase it. Virtually, all papers make it clear that OGs are used less in winter and in extreme temperatures. No author gives a solution to this problem.

Who uses the OGs? The most relevant issue is the low number of elderly people observed using OGs, despite the fact that these are designed purposely for this age group. Authors not included in this review as Cohen, Marsh, Williamson \& Golinelli (2012) found that few older adults use these spaces. So, it is time to stop thinking that these OGs are for older and focus on how they could really use it more. We must distinguish two elements in relation to age. One is what the observations say. That is, how old are the people who go to the OG parks? The age of the visitors suggests that this kind of fitness setting is attractive mainly for adults, irrespective of sex or country (lepsen \& Silva, 2015; Mathias et al., 2018; Szopa \& Sas-Nowosielski, 2016). Interventions are needed to increase the level of PA among individuals to encourage the adoption of an active lifestyle by retirees or pensioners. Retirement is a determinant of involvement in PA. It is important to take advantage of this opportunity to encourage the maintenance or adoption of an active lifestyle within the context of outdoor gyms (Barnett, Van Sluijs \& Ogilvie, 2012).

According to the data, it seems that married people or partners are more active than those who are not or live alone (Pinheiro \& Coelho, 2017). This age group tried to establish some kind of contact or relationship with other people (Romero-Reche, Martos-Fernández \& Hita-Alonso, 2015). Most participants reported not having company to attend $O G$ and having met new people in the neighbourhood after the installation of $O G$. Exercising with others, as well as the presence of other older people in the places where the gyms are located, can contribute to the reduction of depressive symptoms. Depression is a disorder related to several factors, such as sadness, loneliness and social isolation. Most of the users received some family social support from their families (Pinheiro \& Coelho, 2017). Even though social support is an important factor associated with PA, this variable was not enough to encourage active commute to OGs (Silva et al., 2018). Future policies should attempt to integrate other groups.

Unlike other reviews, this one integrates quantitative, qualitative and mixed-methods studies and interventional studies. Also, non-published grey research literature was not included. In some papers, supporting quotations were not reported and this affected the comprehensiveness of data analysis. Not all authors analyse the same parameters or delve into them in the same way. This makes it difficult to first compare those studies and better understand the characteristics and OGs' users behaviours. Still, the findings of this review may help with a better knowledge of the OGs in public open space environments. The ultimate question is how can OG parks be used more and better?

This review is a complement to the one published by Fernández-Rodríguez et al. (2020). That one focused on the users' profile, giving a large amount of information and, in this case, it focuses on the patterns of use of the OGs and their profile. Results suggest that OGs might be acting as catalysts for the adoption of active lifestyles. Practicing in these places can enhance the physical and psychological health benefits; additionally, these places are also associated with a good level of PA.

\section{CONCLUSIONS}

These installations have positive effects, as they not only contribute to increase PA made by their users, but also because they attract people with sedentary lifestyles to make PA. These might contribute to make urban areas more liveable and safer, allowing to use cities' under-occupied public spaces. 
In spite of the different cultural or geographical contexts where they take place, a better knowledge of OGs, would generate a more effective installation, design and use of the OG, giving rise to local and more effective nationals public health promotion policies. These findings are important for local government and health authorities committed to ensuring existing limited open space is purposeful and meets the active recreational needs of an increasing and ageing population. These installations have positive collateral effects, as they not only contribute to increasing PA made by their users, but also because they attract people with sedentary lifestyles to make PA.

It can be said that not only the design of the park (number of machines, shadows, fountains, instructors, services ...) is important. Other aspects can influence in a higher use of OGs; several authors consider that affordability, proximity to neighbours, marketing... were important factors for the success. As referred by the Toronto Charter (2010), it is important that the decision-makers promote PA by increasing access to public spaces. The location of $O G$ seems to be an important factor concerning its potential to be used by the population. An OG located in a green area with several other sports facilities will have a greater impact than an isolated OG. Therefore, the promoting entities must study and analyse the choice of location made. OG may be excellent promoters of PA outdoors in addition to attracting users and becoming a decisive factor in the classification of the public space.

\section{Practical implications}

Few OGs were supported by a user guide and supervised classes by an instructor. An inadequate instructional support may provide a reason for current $O G$ research demonstrating that users did not interact with the equipment with an adequate amount and intensity to achieve health benefits.

The number of equipment and types of equipment did not have a unified standard.

It seems that there are no objective criteria for the selection of the outdoor gym and the machines that make it up.

There were few intervention programs and it's a problem because they are essential to know the health outcomes.

It is necessary to operate in a community setting with local government engagement to maximise the usage of the OGs.

Many authors do not specify the type of methodology. Sometimes the same tool is used with a different name.

OGs take slightly different forms in different countries.

Few articles address a specific aspect in depth. Too many aspects are studied at once. It may be necessary to start addressing OG problems separately, specifically, to better solve them.

Current studies have indicated the existence of potential safety risks due to inappropriate usage behaviours.

The greatest demands for improvement in the OGs from the users were: benches close to the machines, roofs over the equipment, toilets, maintenance, variety of machines, lighting the area, security guards, instructor, better promotion and placing information signs. 


\section{ACKNOWLEDGEMENTS}

This work was supported by the European Union and conducted within the framework of the Erasmus+ project Communities of Practice for a Healthy Lifestyle [grant number 587982-EPP-1-2017-1-NL-EPPKA2$\mathrm{KA}]$.

\section{COMPETING INTERESTS}

The authors declare that they have no competing interests.

\section{REFERENCES}

Barnett I, Van Sluijs E.M., Ogilvie, D. (2012) Physical activity and transitioning to retirement: a systematic review. Am J Prev Med, 43(3), 329-36. https://doi.org/10.1016/j.amepre.2012.05.026

Bettencourt, L., \& Neves, R. (2016). Senior playgrounds in the promotion of physical activity among the elderly - characteristics of use. Journal Kairós Gerontología, 19(1), 59-72. https://doi.org/10.13140/2.1.3203.1684

Chow, H, W. (2013). Outdoor fitness equipment in parks. A qualitative study from older adults' perceptions. BMC Public Health, 13, 12-16. https://doi.org/10.1186/1471-2458-13-1216

Chow, H, W, Mowen A.J. \& Wu, G.L. (2017). Who Is Using Outdoor Fitness Equipment and How? The Case of Xihu Park. Int. J. Environ. Res. Public Health, 14, 448. https://doi.org/10.3390/ijerph14040448

Chow, H., \& Wu, D.-R. (2019). Outdoor Fitness Equipment Usage Behaviors in Natural Settings. Int. J. Environ. Health Res, 16(3), 391. https://doi.org/10.3390/ijerph16030391

Cohen, D.A., Marsh, T., Williamson, S., Golinelli, D. \& McKenzie, T.L. (2012) Impact and costeffectiveness of family Fitness Zones: A natural experiment in urban public parks. Health Place, 18(1), 39-45. https://doi.org/ 10.1016/j.healthplace.2011.09.008

Cooper, H., Hedges, L.V. and Valentine, J.C. (2009). The handbook of research synthesis and metaanalysis. 2nd edition. Sage.

Copeland, J.L., Currie, C., Walker, A., Mason, E., Willoughby, T. \& Amson, A (2017) Fitness Equipment in Public Parks: Frequency of Use and Community Perceptions in a Small Urban Centre. J. Phys. Act. Health, 14(5), 344-352. https://doi.org/10.1123/jpah.2016-0277

Costa, B.G.G, De la Rocha Freitas \& Silva, K.S. (2016). Atividade física e uso de equipamentos entre usuários de duas Academias ao Ar Livre. Rev Bras Ativ Fís Saúde, 21(1), 29-38. https://doi.org/10.12820/rbafs.v.21n1p29-38

Cranney, L., Phongsavan, P., Kariuki, M., Stride, V., Scott, A., Hua, M., \& Bauman, A. (2016). Impact of an outdoor gym on park users' physical activity: A natural experiment. Health Place, 37, 26-34. https://doi.org/10.1016/j.healthplace.2015.11.002

Cranney, L., Shaw, L. \& Phongsavan, P. (2018). Are outdoor gyms located in areas of greatest need and impact? An audit in Sydney, Australia. Annals of Leisure Research, 22(3), 395-403. https://doi.org/10.1080/11745398.2018.1523737

Cozzensa da Silva, M., Meyer lepsen, M., Lucia Caputo, L., Becker Engers, P., Francieli Spohr, C., Fonseca Vilela, G., Carlos Gomes Dorneles, R. (2017). Leisure-time physical activity and associated factors in fitness zones. Rev Bras Cineantropom Hum19(2), 185-195. https://doi.org/10.5007/1980$\underline{0037.2017 v 19 n 2 \mathrm{p} 185}$ 
Del Campo C., Bermúdez, G., Peluffo, S. \& Del Campo, J. (2016) Gimnasios al Aire Libre como estrategia de promoción de salud. Usuarios y características de uso en Uruguay. Tendencias en medicina, 48, 66-73.

Fernández-Rodríguez, E.; Merino-Marban, R.; Romero-Ramos, O.; López-Fernández, I. (2020). Senior Users Profile of the Outdoor Gyms. A Systematic Review. Journal of Sport and Health Research, 12(1), 1-14.

Frieden, T.R. (2015). The Future of Public Health. N Engl J Med, 373, 1748-1754. https://doi.org/10.1056/NEJMsa1511248

Furber, S., Pomroy, H., Grego, S., \& Tavener-Smith, K. (2014). People's experiences of using outdoor gym equipment in parks. Health Promot J Aust, 25(3), 211-211. https://doi.org/10.1071/he14038

Golden, S.D. \& Earp, J.A.L. (2012). Social Ecological Approaches to Individuals and Their Contexts: Twenty Years of Health Education \& Behavior Health Promotion Interventions. Health. Educ. Behav, 39(3), 364-372. https://doi.org/10.1177/1090198111418634

Hernández Aparicio, E., Fernández Rodríguez, E., Merino Marbán, R., Chinchilla Minguet, J.L. (2010) Analysis of the Public Geriatric Parks for Elderly People in Málaga (Spain). Retos. Nuevas tendencias en Educación Física, Deporte y Recreación, 17, 99-102.

Ibiapina, A.R. L, Moura, M.N., Santiago, M.L.E. \& Moura, T.N.B. (2017). Characterization of users and usage pattern of outdoor fitness equipment. Rev Bras Promoç Saúde, 30(4), 1-10. https://doi.org/10.5020/18061230.2017.6688

lepsen, A.M. \& Silva, M.C. (2015). Perfil dos frequentadores das academias ao ar livre da cidade de Pelotas - RS. Rev Bras Ativ Fís Saúde, 413-424. https://doi.org/10.12820/rbafs.v.20n4p413

Jansson, A. K., Lubans, D., Smith, J., Duncan, M. J., Haslam, R., \& Plotnikoff, R. C. (2019). A systematic review of outdoor gym use: Current evidence and future directions. J. Sci. Med. Sport, https://doi.org/10.1016/i.jsams.2019.08.003

Lee, J.L.C., Lo, T.L.T. \& Ho, R.T.H. (2018) Understanding Outdoor Gyms in Public Open Spaces: A Systematic Review and Integrative Synthesis of Qualitative and Quantitative Evidence. Int J Environ Res Public Health, 15(4), 1-15. https://doi.org/10.3390/ijerph15040590

Levinger, P., Panisset, M., Dunn, J., Haines, T., Dow, B., Batchelor, F., ... Hill, K. D. (2019). Exercise intervention outdoor project in the community for older people - the enjoy Senior Exercise Park project translation research protocol. BMC Public Health, 19(1). https://doi.org/10.1186/s12889-019$\underline{7125-2}$

Lima, F.L.R. (2013). Percepção do esforço em idosos nas academias ao ar livre. Revista Brasileira de Prescrição e Fisiologia do Exercício, 7(37), 55-64.

McCormack, G.R., Rock, M., Toohey, A.M. \& Hignell, D. (2010). Characteristics of Urban Parks Associated with Park Use and Physical Activity: A Review of Qualitative Research. Health Place, 16(4), 712-26. https://doi.org/10.1016/i.healthplace.2010.03.003

Mathias, N, G., Filho, J.M., Szkudlarek, A.C., Gallo, L.H., Fermino, R.C. \& Silveira Gomes, A.R. (2018). Motivos para a prática de atividades físicas em uma academia ao ar livre de Paranaguá-PR. Rev Bras Ciênc Esporte. https://doi.org/10.1016/j.rbce.2018.03.030

Mora, Rodrigo (2012). Moving Bodies: Open Gyms and Physical Activity in Santiago. Journal of Urban Design, 17(4), 485-497. https://doi.org/10.1080/13574809.2012.706367

Mora, R., Weisstaub, G., Greene, M. \& Herrmann, G. (2017). Outdoor gyms in Santiago: urban distribution and effects on physical activity. Motriz. J. Phys. Educ, 23(3). https://doi.org/10.1590/s1980-6574201700030005

Nałęcz, H., Ostrowska-Tryzno, A. \& Pawlikowska-Piechotka, A. (2018). Outdoor gyms as an example of outdoor recreation activity in urbanized areas. Tourism/Turyzm, 28(1), 65-71. https://doi.org/10.2478/tour-2018-0008 
Pinheiro, W.L. \& Coelho Filho, J.M. (2017). Profile of elderly users of outdoor gyms for aged people. Rev Bras Promoç Saúde, 30(1), 93-101.

Ramírez, P.C., Camargo, D.M. \& Quiroga, V. (2017) Physical activity in outdoor gym users in Bucaramanga, Colombia. Eur. J. Physiother, 19(1), 54-55. https://doi.org/10.1080/21679169.2017.1381322

Romero-Reche, A., Martos-Fernández P. \& Hita-Alonso, C. (2015) La socialización de las personas mayores en el parque biosaludable. Rev.lb.CC. Act. Fís. Dep, 4(3), 21-33.

Santos Moreno, L., Ribeiro de Oliveira Ferreira, L., Oliveira da Cruz Siqueira, L. (2017) Analysis of committed in the academies activities in outdoor fountain city. Revista Educação Física, V, 19-30.

Scott, A., Stride, V., Neville, L. \& Hua, M. (2014). Design and promotion of an outdoor gym for older adults: a collaborative project. Health Promot. J. Aust, 25, 212-214. https://doi.org/10.1071/HE14037

Salin, M.S., Virtuoso, J.F., Noronha Nepomuceno, A.S., Weiers, G.G., Mazo, G.Z. (2014). Golden Age Gym: reasons for entry, permanence and satisfaction among participating older adults. Rev Bras Cineantropom Desempenho Hum, 16(2), 152-160. https://doi.org/10.5007/1980$0037.2014 \mathrm{v} 16 \mathrm{n} 2 \mathrm{p} 152$

Silva, A.T., Fermino, R.C., Alberico, C.O. \& Reis, R.S. (2016). Fatores associados à ocorrência de lesões durante a prática de atividade física em academias ao ar livre. Rev Bras Med Esporte, 22(4), 267271. https://doi.org/10.1590/1517-869220162204151226

Silva, A.T., Fermino, R.C., Santos Lopes, A.A. Alberico, C.O., \& Reis, R.S. (2018). Distance to fitness zone, use of facilities and physical activity in adults. Rev Bras Med Esporte, 24(2), 157-161. https://doi.org/10.1590/1517-869220182402180439

Silva, M.C., lepsen, A.M., Caputo, E.L., Engers, P.B., Spohr, C.F., Vilela, G.F. \& Gomes Dorneles, R.C. (2017). Leisure-time physical activity and associated factors in fitness zone. Rev Bras Cineantropom Desempenho Hum, 19(2), 185-195. https://doi.org/10.5007/1980-0037.2017v19n2p185

Souza, C.A., Fermino, R.C., Rodriguez Añez, C.R. \& Reis, R.S. (2014). Perfil dos frequentadores e padrão de uso das academias ao ar livre em bairros de baixa e alta renda de Curitiba-PR. Rev Bras Ativ Fís Saúde, 19(1), 86-97. https://doi.org/10.12820/rbafs.v.19n1p86

Stride, V., Cranney, L., Scott, A. \& Hua, M. (2017). Outdoor gyms and older adults-acceptability, enablers and barriers: a survey of park users. Health Promot $J$ Austr, 28, 243-246. https://doi.org/10.1071/HE16075

Szopa, S.\& Sas-Nowosielski, K. (2016). Family recreation Zones as a supportive environment for Physical Activity in the opinion of its users. The new educational, 43, 117-124. https://doi.org/10.15804/tner.2016.43.1.09

Toronto Charter for Physical Activity: A Global Call for Action (2010). Scottish Physical Activity and Health Alliance. http://www.paha.org.uk/Home/

USA Department of Health and Human Services (2018). Physical Activity Guidelines for Americans, 2nd edition. Washington, DC: U.S. Department of Health and Human Services.

WHO. (2017). World health organization. Global strategy on diet, physical activity and health. 10 facts on physical activity.

WHO. (2013). World health organization. Global action plan for the prevention and control of NCDs 20132020.

\section{(9) $\odot \Theta \Theta$}

This work is licensed under a Attribution-NonCommercial-NoDerivatives 4.0 International (CC BY-NC-ND 4.0). 